\title{
EVALUATION OF ESSENTIAL OILS OF Eucalyptus spp. FOR THE CONTROL OF THE SUBTERRANEAN TERMITE Coptotermes gestroi (WASMAN) ${ }^{1}$
}

Talita Vieira Zampieri Mikola ${ }^{2}$, Marcos Roberto Potenza ${ }^{3 *}$, Fabricio Caldeira Reis ${ }^{4}$, Vanessa Coelho da

Silva $^{5}$, Mario Eidi Sato ${ }^{3}$ and Massako Nakaoka Sakita ${ }^{6}$

${ }^{1}$ Received on 04.08.2015 accepted for publication on 24.04.2017.

${ }^{2}$ Instituto Biológico,Pós-Graduação em Sanidade Alimentar e Ambiental no Agronegócio, São Paulo, Brasil. E-mail:

$<$ tatamikola@gmail.com>.

${ }^{3}$ Instituto Biológico, São Paulo, Brasil. E-mail: <potenza@biologico.sp.gov.br> and <mesato@biologico.sp.gov.br>.

${ }^{4}$ Instituto de Pesquisas Energéticas e Nucleares, Pós-Graduação em Tecnologia Nuclear, São Paulo, Brasil. E-mail:

$<$ fabriciocaldeirareis@hotmail.com>.

${ }^{5}$ Centro Universitário São Camilo, Graduada em Ciências Biológicas, São Paulo, Brasil. E-mail: < vanessacoelho1@hotmail.com>.

${ }^{6}$ Instituto Florestal, São Paulo, Brasil. E-mail: <messako_nakaoka@yahoo.com.br>.

*Corresponding author.

ABSTRACT - The subterranean termite Coptotermes gestroi (Wasman) (Isoptera: Rhinotermitidae) is considered one of the main pest species in urban areas in the Southeast Region of Brazil. For the control of this pest, the use of chemical insecticides is recommended, but this method is problematic in urban areas because of the risks of intoxication in the population and environmental contamination along with difficulties in isolating the treated areas. Therefore, it is necessary to find alternative methods aimed at minimizing the undesirable effects on the human population and the environment caused by termite control measures. The objective of this research was to evaluate the toxicity of several essential oils of Eucalyptus (E. camaldulensis, E. citriodora, E. tereticornis, E. pseudoglobulus, and E. maidenii) to the termite C. gestroi, under laboratory conditions. The oils were applied on filter papers that were infested with $C$. gestroi immediately after the treatment. The most toxic oil to the termite was E. citriodora, with the lowest lethal concentration $\left(\mathrm{LC}_{50}\right.$ : $0.63 \%)$ and the shortest lethal time $\left(\mathrm{LT}_{50}:<1 \mathrm{~h}\right.$ at $10 \%, \mathrm{LT}_{50}: 42.4 \mathrm{~h}$ at $\left.1.25 \%\right)$. The least toxic oil was E. pseudoglobulus, with the highest lethal concentration $\left(\mathrm{LC}_{50}: 3.66 \%\right)$ and the longest lethal time $\left(\mathrm{LT}_{50}\right.$ : $11.1 \mathrm{~h}$ at $10 \% \mathrm{LT}_{50}: 473 \mathrm{~h}$ at $1.25 \%$ ). These results indicate the potential for use of eucalyptus essential oils, especially for E. citriodora, for the control of C. gestroi. This article also provides information on the yield from essential oil extraction for different eucalyptus species.

Key words: Isoptera; Plant extracts; Eucalyptus citriodora.

\section{TOXICIDADE DE ÓLEOS ESSENCIAIS DE Eucalyptus spp. PARA O CONTROLE DO CUPIM SUBTERRÂNEO Coptotermes gestroi (WASMAN)}

\begin{abstract}
RESUMO - O cupim subterrâneo Coptotermes gestroi (Wasman) (Isoptera: Rhinotermitidae) é considerada uma das principais espécies-praga, em ambiente urbano, na região Sudeste brasileira. Para o controle dessa praga recomenda-se o uso de inseticidas químicos, mas esse controle torna-se problemático em áreas urbanas, devido aos riscos de intoxicação da população, contaminação do ambiente e dificuldade de isolamento de áreas tratadas. Considerando-se essas dificuldades, há necessidade de se recorrer a métodos alternativos de controle com vistas a minimizar os possíveis efeitos indesejáveis do controle de cupins para a população e ao ambiente. O objetivo desta pesquisa foi avaliar a toxicidade de diversos óleos essenciais de Eucalyptus (E. camaldulensis, E. citriodora, E. tereticornis, E. pseudoglobulus e E. maidenii) ao cupim C. gestroi, em condições de laboratório. As aplicações dos óleos foram feitas sobre papel de filtro, infestadas em seguida com $\boldsymbol{C}$. gestroi. O óleo mais tóxico ao cupim foi o de $\boldsymbol{E}$. citriodora, apresentando a mais baixa concentração letal $\left(C L_{50}: 0,63 \%\right)$ e o menor tempo letal $\left(T L_{50}:<1\right.$ h a $10 \%$; $T L_{50}: 42,4$ h a 1,25\%). Ó́leo menos tóxico foi o de $\boldsymbol{E}$. pseudoglobulus, com a mais alta concentração letal $\left(C L_{50}: 3,66 \%\right)$ e o maior tempo letal (TL $(T 0$ : 11,1 h a $10 \% ; T L_{50}: 473$ h a 1,25\%). Os resultados indicam bom potencial de uso de óleos de eucalipto para o controle de $\boldsymbol{C}$. gestroi, com destaque para $\boldsymbol{E}$. citriodora. No presente artigo, também são apresentados dados de rendimento de extração de óleos essenciais, para as diferentes espécies de eucalipto.
\end{abstract}

Palavras-Chave: Isoptera; Extrato de plantas; Eucalyptus citriodora. 


\section{INTRODUCTION}

Termites belong to the order Isoptera and are considered eusocial insects, because of their characteristics such as care of offspring, presence of reproductive and sterile castes, and overlapping of generations (ZORZENON; POTENZA, 1998; COSTALEONARDO, 2002). Basically, termites feed on cellulosic and lignocellulosic materials, which are found in a variety of forms, such as live or dead wood, grasses, roots, seeds, manure of herbivorous animals, humus, manufactured products, and some products of animal origin such as leather and wool (BERTI FILHO, 1993; ZORZENON; POTENZA, 1998; FONTES; ARAÚJO, 1999; DONOVAN et al., 2001; BIGNELL; ROISIN, 2010; FERREIRA et al., 2011; JACOBS, 2014).

Termites are considered to be very important organisms for the maintenance of decomposition processes and for carbon and nutrient cycling, mainly owing to the biomass of their populations and the variety of their feeding habits (BANDEIRA; VASCONCELLOS, 2002). Despite the benefits provided by these organisms in the ecosystem, termites are better known as pasture and wood pests and for causing the reduction in the planting area by the presence of their nests (termite mounds) on the surface of the soil (RESENDE et al., 2007; FERREIRA et al., 2011).

There are currently 2,882 termite species described, and the neotropical region comprises 562 species (CONSTANTINO, 2012), distributed in seven different families: Hodotermitidae, Kalotermitidae, Mastotermitidae, Rhinotermitidae, Serritermitidae (with occurrence only in Brazil), Termitidae, and Termopsidae (BERTI FILHO, 1993; CONSTANTINO, 2012).

Despite the large number of species known, the proportion of species considered as pests is relatively small. Among the genera that cause more problems, Coptotermes and Heterotermes, known as subterranean termites, and Cryptotermes, known as dry-wood termite, stand out. In these genera, Coptotermes gestroi (Wasman) and Cryptotermes brevis (Walker) are those that cause the greatest losses, and $C$. gestroi is considered the main pest species in the Southeast Region of Brazil (ZORZENON; POTENZA, 1998).

Souza et al. (2009) evaluated the susceptibility of wood of five forest trees to the action of the subterranean termite, $C$. gestroi. As evidence, wood stakes of the following species were used: pine (Pinus sp.) (Pinaceae), chestnut (Bertholletia excelsa) (Lecythidaceae), cabbage angelin (Andira inermis) (Leguminosae, Papilionoideae), masaranduba (Manilkara huberi) (Sapotaceae), and pink lapacho (Tabebuia avellanedae) (Bignoniaceae). The results indicated that pine, chestnut, and angelin stakes were more susceptible to attack by the pest. The woods more susceptible to attack by $C$. gestroi were of moderate to light density.

Lelis (1994) estimated a loss of US\$ 3.5 billion caused by termites when surveying 240 buildings in the city of São Paulo from 1973 to 1993. Serpa (1986) verified the presence of termites of the genus Cryptotermes destroying sacred works, painting frames, altars, beams, rafters, slats, and components of the woodwork of roofs of the historic city of Olinda, in Pernambuco (SILVA et al., 2004).

In an urban setting, termites are not problems unique to buildings. The occurrence of a large number of tree species infested by termites in the cities is also noticeable and the insects may infest buildings through underground dispersal or by flocks occurring during mating seasons. Urban trees represent important foci of reinfestations in treated buildings, because these trees serve as shelters for these termites while also being victims of severe termite attacks that cause great damage and may result in plant death (FONTES; BERTI FILHO, 1998).

For the control of these pests, insecticides (WILKEN, 1992; RESENDE etal., 1995; PETERSON, 2010) are usually used and this control method becomes problematic in urban areas due to the risks of intoxication to the population, contamination of open areas, and difficulty in isolating treated areas.

In this aspect, botanical insecticides represent an alternative to synthetic insecticides. Several studies are being carried out to evaluate the effects of natural products, in particular plant essential oils and their components, on termites (RAINA et al., 2007). Park and Shin (2005) reported the effect of essential oils with fumigant activity on Reticulitermes speratus (Kolbe). In addition, several other studies have also observed mortality of termites after their exposure to plant essential oils (ZHU et al., 2001, 2003; CHANG; CHENG, 2002; CHAUHAN; RAINA, 2006; MEEPAGALA et al., 2006; REGNAULT-ROGER, 2012; ALMEIDA et al., 2015). 
The objective of this work was to evaluate the essential oils of several Eucalyptus species ( $E$. camaldulensis Derth, E. citriodora Hook, E. tereticornis Smith, E. pseudoglobulus (Naudin ex Maiden), and $E$. maidenii $\mathrm{F}$. Muell for the control of the termite $C$. gestroi. There is no information currently in literature on the susceptibility of $C$. gestroi to eucalyptus essential oils.

\section{MATERIALAND METHODS}

To prepare the essential oils, leaves of E. citriodora, E. tereticornis, and E. camaldulensis were collected at the Experimental Station of Luiz Antonio, and those of E. maidenii and E. pseudoglobulus were collected at the Experimental Station of Itapeva, both belonging to Instituto Florestal (Table 1). The oils were extracted at the Laboratory of Phytochemistry of the Section of Wood and Forest Products of Instituto Florestal. A high pruning shear was used to collect enough material for extraction. For distillation of essential oils, the leaves were dried in the shade, at room temperature and in a ventilated place, processed in a knife and hammer mill, and subjected to hydrodistillation in a Clevenger apparatus modified by Wasicky (1963). The material was subjected to extraction for 4 hours. The percentage by weight of the material used was calculated by measuring the volume of the essential oils obtained.

In order to obtain the $C$. gestroi workers used in this study, corrugated cardboard traps adapted from Camargo-Dietrich and Costa-Leonardo (2003) were installed in the facilities of Instituto Biológico, in São Paulo, SP (State of São Paulo). Traps were prepared using PET bottle (Poly Ethylene Terephthalate) with a size of $15 \mathrm{~cm}$ in height $x 8.5 \mathrm{~cm}$ in diameter. Inside the bottles, a roll of corrugated paperboard $(2.0 \mathrm{~m}$ long $\mathrm{x} 11 \mathrm{~cm}$ wide) was placed. The traps were buried with the opening facing down.

To perform the toxicological tests, the method of filter paper impregnated with the products was used, as described by Takematsu (1983). The essential oils were diluted to $10.0 \%, 5.0 \%, 2.5 \%$, and $1.25 \%$. An amount of $0.5 \mathrm{ml}$ of the product was applied to the filter paper ( $7 \mathrm{~cm}$ in diameter). A control, without oil application, was also prepared.

The experiment was conducted in a completely randomized design, with five replicates. Each plot consisted of 20 C. gestroi workers placed on a treated filter paper disk in a Petri dish. The insects were kept in an incubator chamber at $25 \pm 2{ }^{\circ} \mathrm{C}$ and $70 \pm 10 \%$ relative humidity. The evaluations were performed after $1,2,3,4,24,48$, and 72 hours after termite exposure to eucalyptus essential oils. Tests in which the termite mortalities in the control were equal to or greater than $10 \%$ were not considered in this study.

The lethal concentrations $\left(\mathrm{LC}_{50}\right)$ of the essential oils were estimated by Probit analysis (FINNEY, 1971), using the POLO PLUS program (LEORA SOFTWARE, $2003)$. Lethal times $\left(\mathrm{LT}_{50}\right)$ were also estimated for concentrations of $1.25 \%$ and $10 \%$, using the same statistical program.

\section{RESULTS}

The extraction yield of the essential oils is shown in Table 2. The eucalyptus species that presented the highest essential oil content in leaves was $E$. pseudoglobulus $(3.72 \%)$, followed by E. maidenii $(2.72 \%)$

All tested oils caused $100 \%$ mortality for $C$. gestroi at the concentration of $10 \%$. At $5 \%$ concentration, only the oils of E. citriodora, E. tereticornis, and E. maidenii caused mortality rates equal to or greater than $80 \%$. At the concentration of $1.25 \%$, only E. citriodora oil caused mortality equal to or above $80 \%$ (Figure 1 ).

\subsection{Estimates of lethal concentrations}

The mortality data of $C$. gestroi, for the different essential oils tested, fitted the Probit model ( $X^{2}$ not significant, $p$ $>0.05)$. The oil of E. citriodora presented the lowest median lethal concentration $\left(\mathrm{LC}_{50}: 0.63 \%\right.$ ), being significantly lower than the other essential oils, based on the criterion of nonoverlapping of the $\mathrm{LC}_{50}$ confidence intervals at $95 \%$ probability (Table 3).

The other essential oils tested (E. camaldulensis, E. tereticornis, E. pseudoglobulus, and E. maidenii) presented $\mathrm{LC}_{50}$ values equal to or above $2.95 \%$, and there were no statistical differences among these treatments (Table 3).

The highest $\mathrm{LC}_{50}$ was observed for $E$. pseudoglobulus oil $\left(\mathrm{LC}_{50}: 3.66 \%\right)$, which was 5.8 times higher than the $\mathrm{LC}_{50}$ estimated for E. citriodora.

\subsection{Estimation of lethal times}

The oil that provided the fastest control of $C$. gestroi was of E. citriodora, with an estimated mean 
Table 1 - Eucalyptus species (family: Myrtaceae): common name, collecting place, geographical coordinates, and plant parts used in the study.

Tabela 1 - Espécies de Eucalyptus (família: Myrtaceae): nome vulgar, local de coleta, coordenadas geográficas, partes das plantas utilizadas no estudo.

\begin{tabular}{|c|c|c|c|c|}
\hline Species & Common name & Place of collection & Geographical coordinates & Part used \\
\hline E. citriodora & Lemon-scented Gum & Exp. Sta. of Luiz Antonio & $\begin{array}{c}21^{\circ} 31^{\prime} \text { to } 21^{\circ} 41^{\prime} \mathrm{S} 47^{\circ} 40^{\prime} \\
\text { to } 47^{\circ} 51^{\prime} \mathrm{W}\end{array}$ & Leaves \\
\hline E. maidenii & Maiden's Gum & Exp. Sta. of Itapeva & $\begin{array}{c}24^{\circ} 02^{\prime} \text { to } 24^{\circ} 06^{\prime} \mathrm{S} 49^{\circ} 03^{\prime} \\
\text { to } 49^{\circ} 08^{\prime} \mathrm{W}\end{array}$ & Leaves \\
\hline E. pseudoglobulus & Blue Gum & Exp. Sta. of Itapeva & $\begin{array}{c}24^{\circ} 02^{\prime} \text { to } 24^{\circ} 06^{\prime} \mathrm{S} 49^{\circ} 03^{\prime} \\
\text { to } 49^{\circ} 08^{\prime} \mathrm{W}\end{array}$ & Leaves \\
\hline E. tereticornis & Forest Red Gum & Exp. Sta. of Luiz Antonio & $\begin{array}{c}21^{\circ} 31^{\prime} \text { to } 21^{\circ} 41^{\prime} \mathrm{S} 47^{\circ} 40^{\prime} \\
\text { to } 47^{\circ} 51^{\prime} \mathrm{W}\end{array}$ & Leaves \\
\hline E. camaldulensis & River Red Gum & Exp. Sta. of Luiz Antonio & $\begin{array}{c}21^{\circ} 31^{\prime} \text { to } 21^{\circ} 41^{\prime} \mathrm{S} 47^{\circ} 40^{\prime} \\
\text { to } 47^{\circ} 51^{\prime} \mathrm{W}\end{array}$ & Leaves \\
\hline
\end{tabular}

Table 2 - Output of essential oils in different Eucalyptus species.

Tabela 2 - Rendimento de óleos essenciais em diferentes espécies de Eucalyptus.

\begin{tabular}{lccc}
\hline Species & Amount used(in g of leaves) & Oil yield(in mL) & Oil yield (\%) \\
\hline E. citriodora & 503.21 & 6.66 & 1.32 \\
E. maidenii & 330.40 & 9.00 & 2.72 \\
E. pseudoglobulus & 295.40 & 11.00 & 3.72 \\
E. tereticornis & 577.52 & 7.00 & 1.21 \\
E. camaldulensis & 473.92 & 5.00 & 1.05 \\
\hline
\end{tabular}
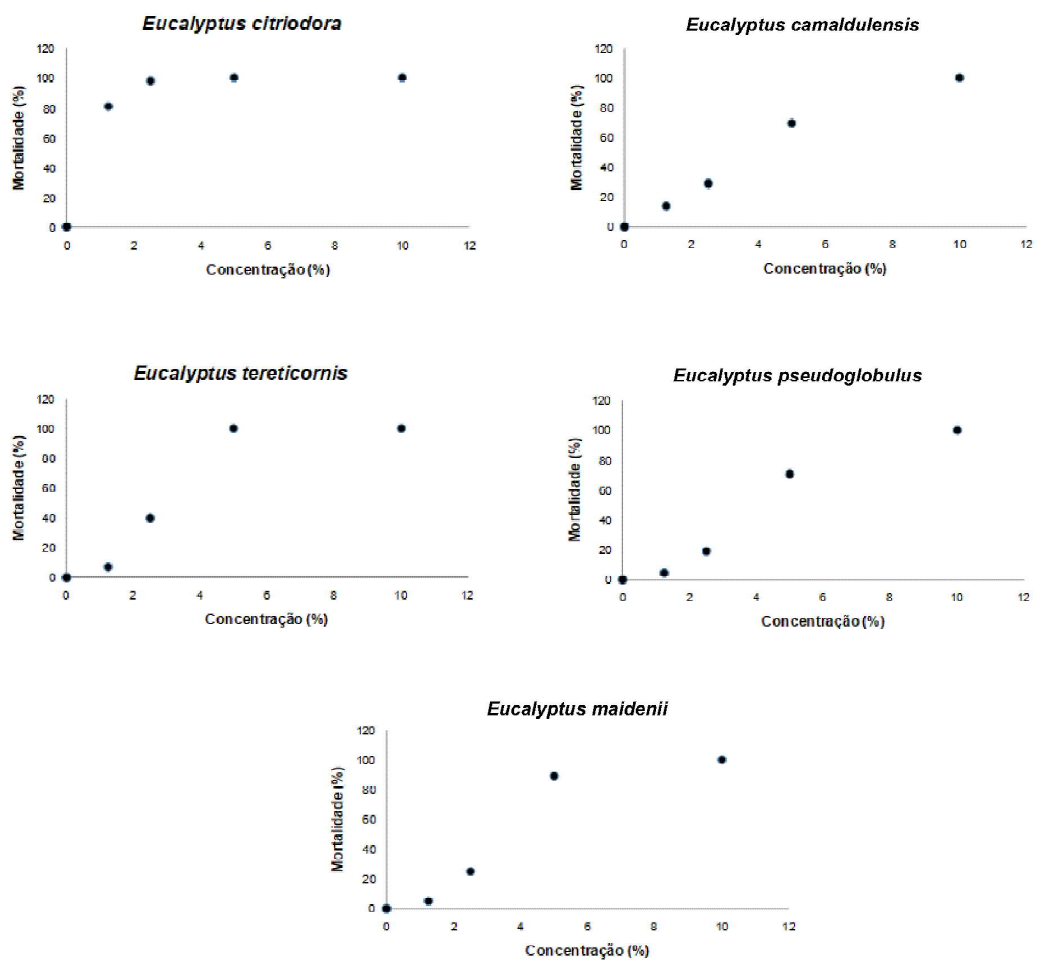

Figure 1 - Toxicity of different eucalyptus essential oils to Coptotermes gestroi: percentage of mortality at 72 hours after the initial exposition of the termites to the oils.

Figura 1 - Toxicidade de diferentes óleos essenciais de eucalipto a Coptotermes gestroi: porcentagens de mortalidade 72 horas após o início da exposição dos cupins aos óleos.

Revista Árvore. 2017;41(2):e410217 
Table 3 - Lethal concentrations (\%) of eucalyptus essential oils for Coptotermes gestroi, at 72 hours after the initial exposure of the termites to the oils: botanical species, total number of termites tested $(n)$, median lethal concentration $\left(\mathrm{LC}_{50}\right)$, slope and standard error, chi-square $\left(X^{2}\right)$, and degree of freedom (d.f.).

Tabela 3 - Concentrações letais (\%) de óleos essenciais de eucalipto para Coptotermes gestroi, 72 horas após o início da exposição dos cupins aos óleos: espécie botânica, número total de cupins testados, concentração letal média $\left(C L_{50}\right)$, coeficiente angular e erro padrão da média, qui-quadrado $\left(X^{2}\right)$, grau de liberdade (g.l.).

\begin{tabular}{lcccc}
\hline Essential oil & $n$ & $\mathrm{LC}_{50}(\%)(95 \%$ C.I. $)$ & Slope \pm SE & $\mathrm{x}^{2}$ \\
\hline E. camaldulensis & 400 & $3.16(0.92-8.94)$ & $3.40 \pm 0.69$ & 5.57 \\
E. citriodora & 500 & $0.63(0.55-0.70)$ & $2.98 \pm 0.24$ & 2.18 \\
E. tereticornis & 500 & $2.95(1.20-4.84)$ & $4.92 \pm 1.36$ & 7.04 \\
E. pseudoglobulus & 400 & $3.66(2.30-5.83)$ & $4.56 \pm 0.69$ & 3 \\
E. maidenii & 400 & $3.06(1.92-4.83)$ & $5.17 \pm 0.83$ & 5 \\
\hline
\end{tabular}

lethal time $\left(\mathrm{LT}_{50}\right)$ of 42.5 hours at the concentration of $1.25 \%$, and less than one hour at the concentration of $10 \%$. At the highest concentration of the product $(10 \%), 100 \%$ mortality was observed in the first 60 minutes (Table 4).

The $\mathrm{LT}_{50}$ for E. citriodora oil at the concentration of $1.25 \%$ was significantly lower than that of $E$. camaldulensis, E. pseudoglobulus, and E. maidenii oils. The E. tereticornis oil did not differ statistically from that of E. citriodora, with $\mathrm{LT}_{50}$ of 71.6 hours at the concentration of $1.25 \%$, and less than one hour at the concentration of $10 \%$ (Table 4 ). The $E$. pseudoglobulus oil presented the longest $\mathrm{LT}_{50}(473.1$ $\mathrm{h}$ or $19.7 \mathrm{~d}$ ), at the concentration of $1.25 \%$, with a value 11.1 times higher than that estimated for E. citriodora.

\section{DISCUSSION}

With the exception of E. pseudoglobulus, for which no citations were found regarding the yield of essential oils, the other eucalyptus species tested (E. citriodora, E. maidenii, E. tereticornis, E. camaldulensis) presented yields similar to or slightly higher than those reported in literature. Yields of essential oils lower than those observed in the present study were reported by some authors for E. maidenii (1\%), E. tereticornis (0.4 to $0.5 \%$ ), and E. camaldulensis (0.32\%) (GUENTHER, 1950; SILVA et al., 2006). Variable yields of essential oils were reported for E. citriodora ( 0.5 to $2.0 \%$ ), E. camaldulensis (0.2 to $2.8 \%$ ), and E. tereticornis (0.9 to $1.0 \%$ ) (LASSAK, 1988; DORAN, 1991; VITTI; BRITO, 2003; VIEIRA, 2004; SILVA et al., 2006).

The effectiveness of $E$. citriodora essential oil in termite (Reticulitermes speratus) control was also reported by Park and Shin (2005), who observed a highly toxic fumigant effect of the product (at $3.5 \mu \mathrm{L} / \mathrm{L}$ of air), one day after application.
Siramon et. al. (2009) also reported the toxic effect of essential oils from leaves of E. camaldulensis to Coptotermes formosanus Shiraki. The tests showed that E. camaldulensis essential oils had toxicity by fumigant effect and residual contact, with $\mathrm{LC}_{50}$ values ranging from 12.68 to $17.50 \mathrm{mg} / \mathrm{g}$ filter paper $(8.7 \mathrm{~cm}$ in diameter) by residual contact and between 12.65 and $17.50 \mathrm{mg} /$ Petri dish $\left(100 \mathrm{~cm}^{3}\right)$ by fumigation. The compounds p-cymene and gamma-terpinene were the main responsible components for residual contact toxicity, and 1.8-cineol (eucalyptol) was responsible for the fumigant effect. In studies of mechanisms of action of the essential oils of E. camaldulensis, acetylcholinesterase inhibitory activity was observed, demonstrating common symptoms of neurotoxic compounds for C.formosanus (SIRAMON et al., 2009).

The $\mathrm{LC}_{50}$ reported by Siramon et. al. (2009) for E. camaldulensis essential oil by residual contact (12.7 to $17.5 \mathrm{mg} / \mathrm{g}$ filter paper) for C. formosanus was similar to that observed ( $15.8 \mathrm{mg} / \mathrm{g}$ filter paper) for C. gestroi, in the present experiment.

Long lethal times required to kill termites, as observed for E. maidenii and E. pseudoglobulus (up to 19.7 d) in C. gestroi, were also reported by Chang and Cheng (2002), when evaluating the effect of essential oils of Cinnamomum osmophloeum Kaneh on C. formosanus. For several components (eugenol, $\alpha$-terpineol, geraniol, benzaldehyde, and neral) of the essential oils of this plant, an increase in termite mortality was observed when the evaluation time was extended up to 14 days.

These results indicate the potential of using eucalyptus oils, especially E. citriodora oils, for the control of C. gestroi. Studies under field conditions, through tree applications and/or wood or soil treatment, are needed to prove the efficacy of eucalyptus essential oils in the control of the subterranean termite. 
Table 4 - Lethal time (hours) of eucalyptus essential oils, at the concentrations of $1.25 \%$ and $10 \%$, for Coptotermes gestroi: botanical species, medial lethal time $\left(\mathrm{LT}_{50}\right)$, slope and standard error, chi-square $\left(X^{2}\right)$, and degree of freedom (d.f.).

Tabela 4 - Tempos letais (horas) para óleos essenciais de eucalipto, nas concentrações de 1,25\% e 10\%, para Coptotermes gestroi: espécie botânica, tempo letal médio $\left(T L_{50}\right)$, coeficiente angular e erro padrão da média, qui-quadrado $\left(X^{2}\right)$, grau de liberdade (g.l.).

\begin{tabular}{|c|c|c|c|c|c|}
\hline Essential oil & Concentration( $\%)$ & $\mathrm{LT}_{50}(\mathrm{~h})(95 \%$ C.I. $)$ & Slope \pm SE & $\mathrm{x}^{2}$ & d.f. \\
\hline \multirow[t]{2}{*}{ E. camaldulensis } & 1.25 & $104.74(80.48-158.16)$ & $1.83 \pm 0.25$ & 6.02 & 5 \\
\hline & 10.0 & $0.43(0.03-0.97)$ & $1.18 \pm 0.26$ & 2.24 & 5 \\
\hline \multirow[t]{2}{*}{ E. citriodora } & 1.25 & $42.45(28.08-73.15)$ & $1.94 \pm 0.31$ & 8.70 & 5 \\
\hline & 10.0 & $<1 *$ & - & - & - \\
\hline \multirow[t]{2}{*}{ E. tereticornis } & 1.25 & $71.62(58.45-93.45)$ & $1.84 \pm 0.20$ & 9.56 & 5 \\
\hline & 10.0 & $<1 *$ & - & - & - \\
\hline \multirow[t]{2}{*}{ E.pseudoglobulus } & 1.25 & $473.13(223.07-2265.63)$ & $1.21 \pm 0.23$ & 4.83 & 5 \\
\hline & 10.0 & $11.09(7.43-16.93)$ & $2.67 \pm 0.33$ & 8.87 & 5 \\
\hline \multirow[t]{2}{*}{ E. maidenii } & 1.25 & $136.85(97.80-234.14)$ & $1.59 \pm 0,22$ & 8.41 & 5 \\
\hline & 10.0 & $7.03(6.19-8.15)$ & $3.44 \pm 0.25$ & 6.39 & 5 \\
\hline
\end{tabular}

* Mortality of $100 \%$ in less than 1 hour.

\section{CONCLUSIONS}

Based on our results, the following conclusions can be drawn: a) C. gestroi termites were susceptible to the treatments with essential oils of E. camaldulensis, E. citriodora, E. tereticornis, E. pseudoglobulus, and E. maidenii, with mortality rates up to $100 \%$; b) $E$. citriodora oil was the most toxic to $C$. gestroi $\left(\mathrm{LC}_{50}\right.$ : $0.63 \%$ ), whereas the least toxic oil was from $E$. pseudoglobulus $\left(\mathrm{LC}_{50}: 3.66 \%\right)$; c) The use of E. citriodora and $E$. tereticornis oils resulted in the shortest lethal times for C. gestroi $\left(\mathrm{LT}_{50} \leq 72 \mathrm{~h}\right.$ at $1.25 \%$ ); d) $E$. pseudoglobulus oil presented the slowest action for the control of the subterranean termite C. gestroi $\left(\mathrm{LT}_{50}\right.$ : $473 \mathrm{~h}$ at $1.25 \%$ ).

\section{ACKNOWLEDGMENTS}

The authors thank CNPq-Brazil (National Council for Scientific and Technological Development - Brazil) for providing the scholarships (PIBIC) to Fabrício Caldeira Reis and Vanessa Coelho da Silva and for Mario E. Sato's research fellowship; the authors also thank FAPESP (São Paulo Research Foundation) for the Technical Training (TT3) fellowship (Process: 2008/ 08526-3) to the first author.

\section{REFERENCES}

ALMEIDA, M.L.S; OLIVEIRA, A.S.; RODRIGUES, A.A.; CARVALHO, G.S.; SILVA, L.B.; LAGO, J.H.G.; CASARIN, F.E. Antitermitic activity of plant essential oils and their major constituents

Revista Árvore. 2017;41(2):e410217 against termite Heterotermes sulcatus (Isoptera: Rhinotermitidae). Journal of Medical Plants Research, v.9, n.4, p.97-103, 2015.

BANDEIRA, A.G.; VASCONCELLOS, A. A quantitative survey of termites in a gradient of disturbed highland forest in Northeastern Brazil (Isoptera). Sociobiology, v.39, p.429-439, 2002.

BERTI FILHO, E. (Coord.). Manual de pragas em florestas - cupins ou térmitas. v.3. São Paulo: IPEF/SIF, 1993. 56p.

BIGNELL, D.E.; ROISIN, Y.; LO, N. Biology of termites: a modern synthesis: a modern synthesis. Springer: London. 2010. 563p.

CAMARGO-DIETRICH, C.R.R. de; COSTALEONARDO, A.M. População e território de forrageamento de uma colônia de Heterotermes tunis (Hagen) (Isoptera, Rhinotermitidae).

Revista Brasileira de Zoologia, v.20, n.3, p.397-399, 2003.

CHANG, S.T.; CHENG, S.S. Antitermitic activity of leaf essential oils and components from Cinnamomum osmophleum. Journal of Agricultural and Food Chemistry, v.50, p.1389-1392, 2002.

CHAUHAN, K.R.; RAINA, A.K. Modified vetiver oil: economic biopesticide. In: RIMANDO, A.M.; DUKE, S.O. (Eds.). Natural products for 
pest management. Washington, $\mathrm{DC}$ : American Chemical Society, 2006. p.210-218.

CONSTANTINO, R. 2012. On-Line Termites Database. (Disponível em: http://www.unb.br/ib/ zoo/docente/constant/catal/catnew.html). Acesso em: 4. dez. 2012.

COSTA-LEONARDO, A.M. 2002. Cupins-praga: morfologia, biologia e controle. Universidade Estadual Paulista: Rio Claro. 2002. 128 p.

DONOVAN, S.E.; EGGLETON, P.; BIGNELL, D.E. Gut content analysis and a new feeding group classification of termites. Ecological Entomology, v.26, n.4, p.356-366, 2001.

DORAN, J.C. Commercial sources, uses, formation, and biology. In: BOLAND, D.J.; BROPHY, J.J.; HOUSE, A.P.N. (Eds.).

Eucalyptus leaf oils: use, chemistry, distillation and marketing. Melbourne: Inkata, 1991.p.11-28.

FERREIRA, E.V.O.; MARTINS, V.; JUNIOR, A.V.I.; GIASSON, E.; NASCIMENTO, P. C. Ação dos térmitas no solo. Ciência Rural, v.41, n.5, p.804-811, 2011.

FINNEY, D.J. Probit analysis. 3. ed. London: Cambridge University Press, 1971. 315p.

FONTES, L.R.; ARAUJO, R.L. de. Os cupins. In: MARICONI, F. A. M. (Coord.). Insetos e outros invasores de residências. Piracicaba: FEALQ, 1999. p.35-90.

FONTES, L.R.; BERTI FILHO, E. Cupins: o desafio do conhecimento. Piracicaba: FEALQ, $1998.512 \mathrm{p}$.

GUENTHER, E. The essential oils. v.4. New York: D. Van Nostrand Company Inc., 1950. 752p.

JACOBS, S. Eastern subterranean termites (revised 2014). Disponível em: http://ento. psu.edu/extension/factsheets/termites. Acesso em 12 Fev 2015.

LASSAK, E.V. The Australian Eucalyptus oil industry, past and present. Chemistry in Australia, v.55, p. 396-398, 1988.
LELIS, A.T. Termite problem in São Paulo city Brazil. In: CONGRESS OF THE INTERNATIONAL UNION FOR THE STUDY OF SOCIAL INSECTS, 12., 1994, Paris. Proceedings... Paris: 1994, p.42-46.

LEORA SOFTWARE. In: ROBERTSON, J.L., PREISLER, H.K., RUSSEL, R.M. Polo Plus Probit and Logit Analysis, User's Guide. Berkeley, 2003. p.36.

MEEPAGALA, K.M.; OSBRINK, W.; STURTZ, G.; LAX, A. Plant-derived natural products exhibiting activity against Formosan subterranean termite (Isoptera: Rhinotermitidae). Pest Management Science, v.62, p.565-570, 2006.

PARK, I.K.; SHIN, S.C. Fumigant activity of plant essencial oils and components from garlic (Allium sativum) and clover bud (Eugenia caryophyllata) oils against the Japanese termite (Reticulitermes speratus Kolbe). Journal of Agricultural and Food Chemistry, v.53, p.4388-4392, 2005.

PETERSON, C. Considerations of soil-applied insecticides for termite control. Outlooks on Pest Management, v.21, n.2, p. 89-93, 2010.

RAINA, A.; BLAND, J.; DOOLITTLE, M.; LAX, A.; BOOPATHY, R.; FOLKINS, M. Effects of orange oil extract on the Formosan subterranean termite (Isoptera: Rhinotermitidae). Journal of Economic Entomology, v. 100, n. 3, p. 880885, 2007.

REGNAULT-ROGER, C.; VINCENT, C.; ARNASON, J.T. Essential oils in insect control: low-risk products in a high-stakes world. Annual Review of Entomology, v. 57, p.405-424, 2012.

RESENDE, V.F.; ZANUNCIO, J.C.; GUEDES, R.N.C.; NOGUEIRA, P.B. Efeitos comparativos do carbosulfan e do aldrin na proteção de mudas de eucaliptos contra cupins subterrâneos. Anais da Sociedade Entomológica do Brasil, v.24, n.3, p.645-648, 1995.

RESENDE, M.; CURI, N.; REZENDE, S.B.; CORRÊA, G.F. Pedologia: base para distinção dos ambientes. 5.ed. rev. Lavras- MG: UFLA, 2007.322p.

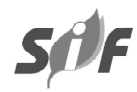

Revista Árvore. 2017;41(2):e410217 
SERPA, F.G. Cupim, uma ameaça a Olinda, patrimônio da humanidade. São Paulo: ABPM, 1986. 8p. (Boletim, 40).

SILVA, J.C.; LOPEZ, A.G.C.; OLIVEIRA, J.T.S. Influência da idade na resistência natural da madeira de Eucalyptus grandis W. Hill ex. Maiden ao ataque de cupim de madeira seca

(Cryptotermes brevis). Revista Árvore, v.28, n.4, p.583-587, 2004.

SILVA, P.H.M.; BRITO, J.O.; JUNIOR, F.G.S. Potential of eleven Eucalyptus species for the production of essential oils. Scientia Agricola, v.63, n.1, p.85-89, 2006.

SIRAMON, P.; OHTANI, Y.; ICHIURA, H. Biological performance of Eucalyptus camaldulensis leaf oils from Thailand against the subterranean termite Coptotermes formosanus Shiraki. Journal of Wood Science, v.55, n.1, p.41-46, 2009

SOUZA, J.H. de; MENEZES, E.L.A.; MAURI, R.; MENEZES, E.B. Susceptibility of five forest species to Coptotermes gestroi. Revista Árvore, v.33, n.6, p.1043-1050, 2009.

TAKEMATSU, A.P. Suscetibilidade de Sitophilus zeamais Mots, (ColeopteraCurculionidae) de diferentes regiões do estado de São Paulo, a inseticidas fosforados e piretróides em condições de laboratório. 1983. 77f. Dissertação (Mestrado em Entomologia) - Universidade de São Paulo, Piracicaba, 1983.

VIEIRA, I.G. Estudos caracteres silviculturais e de produção de óleos essenciais de progenies de Corymbia citriodora (Hook) K.D. Hill \& L. A. S. Johnson procedente de Anhembi, SP, Brasil, Ex. Atherton QLD, Austrália. 2004. 100f. Dissertação (Mestrado) - ESALQ/USP, Piracicaba, 2004.

VITTI, A.M.S.; BRITO, J.O. Óleo essencial de Eucalipto. Piracicaba: ESALQ/USP, 2003. 26p. (Documentos Florestais, 17).

WASICKY, R. Uma modificação do aparelho de clevenger para extração de óleos essenciais. Revista Faculdade de Farmácia e Bioquímica, v.1, p. 7-81, 1963.

WILCKEN, C.F. Danos de cupins subterrâneos Cornitermes sp. (Isoptera: Termitidae) em plantios de Eucalyptus grandis e controle com inseticidas no solo. Anais da Sociedade Entomológica do Brasil, Porto Alegre, v.21, n.3, p.329 - 338, 1992.

ZHU, B.C.R.; HENDERSON, G.; CHEN, F.; FEI, H.; LAINE, R.A. Evaluation of vetiver oil and seven insect-active essencial oil against the Formosan subterranean termite. Journal of Chemical Ecology, v.27, p.1617-1625, 2001.

ZHU, B.C.R.; HENDERSON, G.; YU, H.; LAINE, R.A. Toxicity and repellency of patchouli oil and patchouli alcohol against Formosan subterranean termits Coptotermes formosanus Shiraki (Isoptera: Rhinotermitidae). Journal of Agricultural and Food Chemistry, v. 51, p. 4585-4588, 2003.

ZORZENON, F.J.; POTENZA, M.R. Cupins: pragas em áreas urbanas. São Paulo, Instituto Biológico, 1998. 40 p. (Boletim Técnico, 10). 